\title{
Persepsi Mahasiswa Terhadap Pembelajaran Daring Pada Masa Pandemi Covid-19 (Studi Mahasiswa FIK UNW Mataram)
}

\author{
Nurul Auliya Kamila ${ }^{1 *}$, Ziadatul Munawarah ${ }^{2}$ \\ 1,2 Program Studi D3 Kebidanan, Fakultas IImu Kesehatan (FIK), Universitas Nahdlatul Wathan \\ Mataram, Indonesia \\ *email: mila_yk2007@yahoo.com
}

\begin{abstract}
The Covid-19 pandemic has changed the learning system in Indonesia from face-to-face in a room to online learning through electronic devices. Teachers/lecturers, students and students are forced to study from home because face-to-face learning is abolished to prevent the transmission of COVID-19. The online learning model is still very rarely carried out by several universities considering that campus readiness in carrying out online lectures takes time, as well as student readiness to take online lectures requires time and process, therefore it is necessary to map students' perceptions of the implementation of online learning for students. The purpose of this study was to determine the perceptions of students of the Faculty of Health Sciences UNW Mataram (FIK UNW Mataram) towards online learning during the Covid 19 Pandemic. This study was a descriptive study with a cross sectional approach. The sample of this study was all students of FIK UNW Mataram which consisted of 3 study programs, namely D3 Pharmacy, D3 Midwifery, and D3 Nursing, totaling 247 people. This research was conducted in the Odd semester 2020/2021. The instrument used is a closed questionnaire about students' perceptions of online learning with answers that are degraded according to the Likert scale and have been validated by experts. The analysis technique used is descriptive. The results showed that descriptive analysis of the perception data of FIK UNW Mataram students towards online learning resulted in an average of 2.06 or a fairly good category. Therefore, it can be concluded that online learning at FIK UNW Mataram in the 2020/2021 Odd Semester was less effective.
\end{abstract}

Keywords: Perseption; online learning; covid-19

\section{Abstrak}

Masa Pandemi Covid-19 telah mengubah system pembelajaran di Indonesia dari yang tatap muka dalam ruangan menjadi pembelajaran online melalui perangkat elektronik. Guru/dosen, siswa dan mahasiswa terpaksa belajar dari rumah karena pembelajaran tatap muka ditiadakan untuk mencegah penularan covid-19. Model pembelajaran Daring masih sangat jarang dilakukan oleh beberapa perguruan tinggi mengingat kesiapan kampus dalam melaksanakan perkuliahan daring ini membutuhkan waktu, begitu juga kesiapan mahasiswa dalam mengikuti perkuliahan daring ini membutuhkan waktu dan proses, oleh sebab itu diperlukan adanya pemetaan persepsi mahasiswa terhadap pelaksanaan pembelajaran daring pada mahasiswa FIK UNW Mataram. Tujuan penelitian ini adalah untuk mengetahui persepsi mahasiswa Fakultas Ilmu Kesehatan terhadap pembelajaran daring pada masa Pandemi Covid 19. Penelitian ini adalah penelitian deskriptif dengan pendekatan cross sectional. Sampel penelitian ini adalah seluruh mahasiswa FIK UNW Mataram yang terdiri dari 3 program studi yaitu D3 Farmasi, D3 Kebidanan, dan D3 Keperawatan yang berjumlah 247 orang. Penelitian ini dilaksanakan pada semester Ganjil 2020/2021. Instrument yang digunakan adalah angket tertutup tentang persepsi mahasiswa tentang pembelajaran daring dengan jawaban berdegradasi sesuai skala likert dan telah divalidasi ahli. Teknik analisis yang digunakan adalah deskriptif. Hasil penelitian menunjukkan bahwa analisis deskriptif data persepsi mahasiswa FIK UNW Mataram terhadap pembelajaran daring menghasilkan ratarata sebesar 2.06 atau kategori cukup baik. Oleh sebab itu, dapat disimpulkan bahwa 


\section{Prosiding Seminar Kesehatan Nasional Lembaga Penelitian dan Pengabdian Masyarakat Universitas Muhammadiyah Pekajangan Pekalongan}

pembelajaran daring di FIK UNW Mataram pada Semester Ganjil 2020/2021 berlangsung kurang efektif.

Kata kunci: Persepsi; pembelajaran daring; covid-19

\section{Pendahuluan}

Pada awal 2020, dunia dikejutkan dengan mewabahnya pneumonia baru yang bermula dari Wuhan, China yang kemudian menyebar dengan cepat ke lebih dari 190 negara. Wabah ini diberi nama coronavirus disease 2019 (COVID-19) yang disebabkan oleh Severe Acute Respiratory Syndrome Coronavirus-2 (SARS-CoV-2) [1]. Penyebaran penyakit ini telah memberikan dampak luas secara sosial dan ekonomi. Saat ini, penyebaran SARS-CoV-2 dari manusia ke manusia menjadi sumber transmisi utama sehingga penyebaran menjadi lebih agresif [2]. Untuk menurunkan prevalensi penularan Covid-19 kepada masyarakat luas, maka peran tenaga kesehatan diharapkan dapat memberikan edukasi kepada masyarakat dalam hal pencegahan penularan Covid-19 seperti pemahaman dalam menjaga kebersihan diri dengan cuci tangan lebih sering, memakai masker, melakukan social distancing, mewaspadai gejala Batuk, Nyeri dada, sakit tenggorokan agar segera mendatangi petugas kesehatan. [3]

Wabah Covid-19 membuat masyarakat Indonesia khawatir karena banyaknya warga yang terkena dampak penularan virus tersebut. Oleh karenanya pemerintah RI mengambil kebijakan Pembatasan Sosial Berskala Besar (PSBB) sebagai langkah untuk mengurangi atau memutuskan rantai penyebaran Covid-19 [4]. Menurut surat edaran (SE) Mendikbud Nomor 2 Tahun 2020 tentang pencegahan corona virus disease (Covid-19) pada satuan Pendidikan, kemendikbud telah mengeluarkan kebijakan tentang Pelaksanaan Pembelajaran dilakukan dengan menggunakan metode Pembelajaran Jarak Jauh (PJJ), Daring/Online pada satuan pendidikan sampai dengan kondisi memungkinkan untuk pelaksanaan Pembelajaran dengan Tatap Muka (PTM) sebagai upaya pencegahan penularan dan penyebaran Covid-19 [5]. Petunjuk teknis pembelajarn di rumah yang dikeluarkan pemerintah daerah di Indonesia khususnya di Kota Mataram NTB sesuai dengan surat edaran Gubernur NTB pada 7 Juli 2020 tentang penyelenggaraan pembelajaran satuan pendidikan tahun ajaran 2020/2021 di masa pandemi corona virus, berisi menghentikan pembelajaran tatap muka dan memberlakukan daring bagi semua satuan Pendidikan dengan memanfaatkan berbagai media daring yang disesuaikan dengan fasilitas yang dimiliki sekolah dan perguruan tinggi. [6]

Model pembelajaran daring masih sangat jarang dilakukan oleh beberapa perguruan tinggi mengingat kesiapan kampus dalam melaksanakan perkuliahan daring merupakan suatu kegiatan belajar yang membutuhkan jaringan internet dengan konektivitas, aksesibilitas, fleksibilitas, serta kemampuan untuk memunculkan berbagai jenis interaksi pembelajaran, begitu juga kesiapan mahasiswa dalam mengikuti perkuliahan daring ini membutuhkan waktu dan proses adaptasi [7]. Pembelajaran online adalah sebuah jenis proses pembelajaran yang mengandalakan koneksi internet untuk mengadakan proses pembelajaran, dosen dan mahasiwa dapat melakukan pembelajaran hanya dengan mengadalakan koneksi internet dan mereka tidak perlu ruang kelas untuk melakukan proses pembelajaran. Pelaksanaan pembelajaran daring 


\section{Prosiding Seminar Kesehatan Nasional Lembaga Penelitian dan Pengabdian Masyarakat Universitas Muhammadiyah Pekajangan Pekalongan}

membutuhkan adanya fasilitas sebagai penunjang, yaitu seperti smartphone, laptop, ataupun tablet yang dapat digunakan untuk mengakses informasi dimanapun dan kapanpun [6],[7]. Namun dalam kenyataannya, Pembelajaran online bukan suatu jenis pembelajaran yang tanpa permasalahan dalam prosesnya. Tantangan dari adanya pembelajaran daring salah satunya adalah keahlian dalam penggunaan teknologi dari pihak pendidik maupun peserta didik. [6],[7]

Penerapan pembelajaran daring pada masa Pandemi Covid-19 di Fakultas Ilmu Kesehatan dilakukan penuh secara daring pada awal masa Pandemi, akan tetapi jika melihat kurikulum pembelajaran kesehatan yang membutuhkan keterampilan skill/praktikum maka sesuai edaran Rektor UNW Mataram maka diputuskan untuk melakukan pembelajaran daring sebesar $70 \%$ dan 30\% secara skill di kampus dengan prosedur kesehatan yang ketat. Untuk pembelajaran skill yang dilakukan di lahan praktik seperti di Rumah sakit/Puskesmas ditiadakan. Belum maksimalnya media pembelajaran daring seperti LMS (Learning Management System) di lingkungan FIK UNW Mataram. Oleh karena itu diperlukan adanya pemetaan persepsi mahasiswa terhadap pelaksanaan pembelajaran daring di FIK UNW Mataram.

Pelaksanaan pembelajaran daring di Fakultas IImu Kesehatan Universitas Nahdlatul Wathan Mataram telah berlangsung dengan persentase $70 \%$ daring, dan $30 \%$ luring, selama proses pembelajaran daring belum diketahui secara pasti mengenai persepsi mahasiswa terkait kesiapan, kendala dan pelaksanaan pembelajaran daring. Padahal persepsi mahasiswa sangat mempengaruhi peningkatan peran dan keaktifan mahasiswa dalam penggunaan berbagai media dan teknologi demi sukesnya pembelajaran daring [8]. Hal yang telah dipaparkan tersebut adalah alasan penulis melakukan penelitian ini sberdasarkan kebutuhan informasi untuk menjawab beberapa pertanyaan penelitian mengenai pelaksanaan pembelajaran daring pada masa pandemi Covid-19.

\section{Metode}

Penelitian ini merupakan penelitian deskriptif dengan menggunakan desain potong lintang (cross sectional). Responden penelitian ini adalah seluruh mahasiswa FIK UNW Mataram yang terdiri dari 3 program studi yaitu D3 Farmasi, D3 Kebidanan, dan D3 Keperawtan yang berjumlah 247 orang. Penelitian ini dilaksanakan pada semester Ganjil 2020/2021. Instrument yang digunakan adalah angket tertutup tentang persepsi mahasiswa tentang pembelajaran daring. Instrument mengacu pada indikator persepsi yang dikembangkan oleh Adijaya (2018) [9], yaitu interaksi pembelajaran, manajement pembelajaran, evaluasi pembelajaran, dan lingkungan belajar. Instrument terdiri dari 14 pertanyaan dengan jawaban berdegradasi sesuai skala likert dan telah divalidasi ahli. Angket disebarkan melalui google form pada masing-masing program studi. Rata-rata persepsi dikonversi dalam bentuk kategori yaitu: 


\section{Prosiding Seminar Kesehatan Nasional 2021 Lembaga Penelitian dan Pengabdian Masyarakat Universitas Muhammadiyah Pekajangan Pekalongan}

Tabel 1. Pertanyaan Persepsi Mahasiswa

\begin{tabular}{cl}
\hline Nomor & \multicolumn{1}{c}{ Pertanyaan } \\
\hline 1 & Pembelajaran memudahkan saya berinteraksi dengan dosen \\
2 & Penyampaian materi kurang efektif melalui pembelajaran daring \\
3 & Miskomunikasi antara dosen dan mahasiswa sering terjadi melalui belajar daring \\
4 & Mengemukakan pendapat, pertanyaan lebih mudah melalui pembelajaran daring \\
5 & Diskusi antara dosen dan mahasiswa kurang efektif melalui daring \\
6 & Penyelesaian masalah lebih mudah dan cepat melalui daring \\
7 & Respon/umpan balik lebih kurang efektif pada pembelajaran daring \\
8 & Pembelajaran daring memudahkan saya berinteraksi dengan mahasiswa lainnya \\
9 & Miskomunikasi antar mahasiswa lebih sering terjadi pada pembelajarang daring \\
10 & Diskusi dan kolaborasi antar mahasiswa kurang efektif selama pembelajaran daring \\
11 & Pelaksanaan evaluasi lebih objektif dalam pembelajaran daring \\
12 & Lingkungan belajar mendukung pembelajaran daring \\
13 & Pembelajaran daring meningkatkan aktivitas belajar saya \\
14 & Pembelajaran daring meningkatkan kemandirian saya dalam belajar \\
\hline
\end{tabular}

Tabel 2. Interpretasi Skor Persepsi Mahasiswa

\begin{tabular}{cc}
\hline Rata-rata skor & Interpretasi \\
\hline $3.51-4.00$ & Sangat baik \\
$2.51-3.50$ & Baik \\
$1.51-2.50$ & Cukup Baik \\
$1.00-1.50$ & Kurang Baik \\
\hline
\end{tabular}

\section{Hasil dan Pembahasan}

\section{Hasil}

Adapun hasil penelitian ini dijabarkan sebagai berikut:

a. Asal Program Studi

Tabel 3. Karakteristik Responden Menurut Asal Program Studi

\begin{tabular}{ccc}
\hline Asal Program Studi & $\mathrm{n}$ & $\%$ \\
\hline Diploma III Farmasi & 190 & 77.0 \\
Diploma III Keperawatan & 37 & 15.0 \\
Diploma III Kebidanan & 20 & 8.0 \\
\hline Total & 247 & 100.00 \\
\hline
\end{tabular}

Sumber: Data diolah

Pada tabel diatas, diketahui responden terbanyak berasal dari Diploma III Farmasi sebanyak 190 orang (77\%).

b. Menurut Jenis Media Pembelajaran Daring yang Digunakan

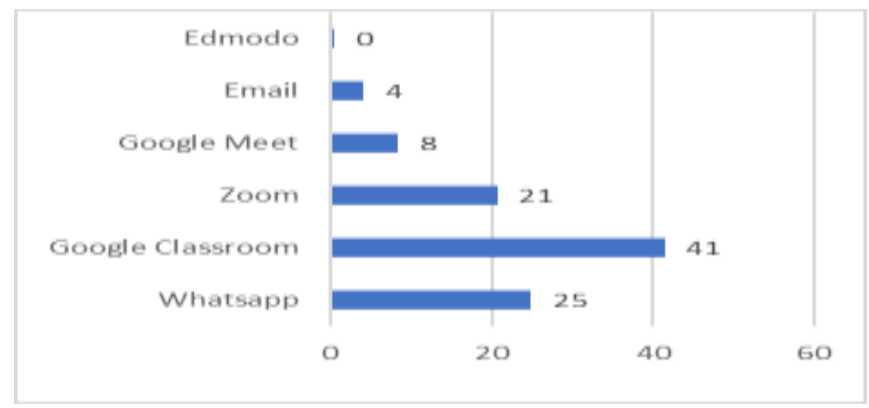

Gambar 1. Penggunaan Media Pemblajaran daring 


\section{Prosiding Seminar Kesehatan Nasional 2021 Lembaga Penelitian dan Pengabdian Masyarakat Universitas Muhammadiyah Pekajangan Pekalongan}

Informasi tentang media pembelajaran daring bahwa sebanyak $41 \%$ mahasiswa menyatakan bahwa mereka paling banyak menggunakan aplikasi Google Classroom sebagai media pembelajaran.

c. Menurut Jenis Komunikasi yang Diminati

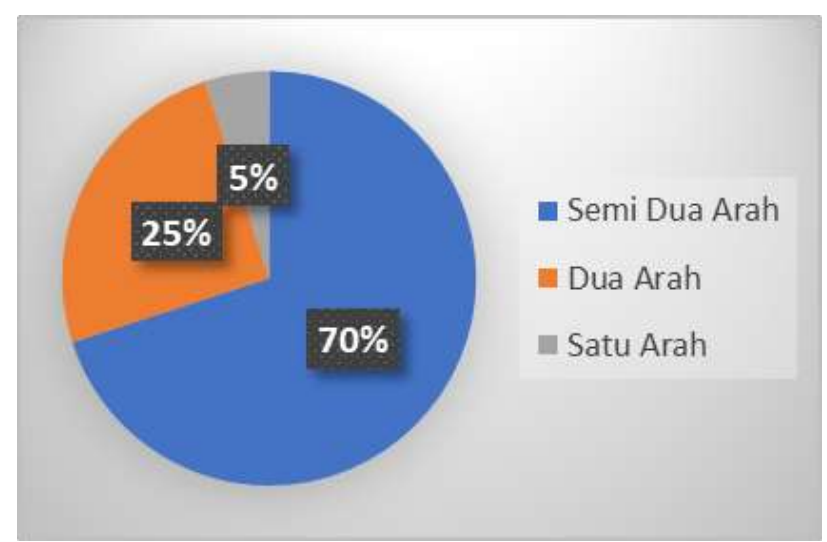

Gambar 2. Jenis Komunikasi dalam Pembelajaran Daring

Berdasarkan hasil survey, diperoleh informasi bahwa dari $70 \%$ respoden mahasiswa lebih menyukai model komunikasi semi dua arah.

d. Persepsi Mahasiswa dalam Pembelajaran Daring

Tabel 4. Persepsi Mahasiwa tentang Pembelajaran Daring

\begin{tabular}{ccccc}
\hline Pertanyaan & SS & S & KS & TS \\
\hline 1 & $0 \%$ & $17 \%$ & $53 \%$ & $30 \%$ \\
2 & $24 \%$ & $55 \%$ & $15 \%$ & $8 \%$ \\
3 & $13 \%$ & $64 \%$ & $18 \%$ & $5 \%$ \\
4 & $2 \%$ & $14 \%$ & $58 \%$ & $26 \%$ \\
5 & $36 \%$ & $45 \%$ & $16 \%$ & $3 \%$ \\
6 & $2 \%$ & $17 \%$ & $63 \%$ & $18 \%$ \\
7 & $26 \%$ & $56 \%$ & $18 \%$ & $0 \%$ \\
8 & $5 \%$ & $22 \%$ & $52 \%$ & $21 \%$ \\
9 & $15 \%$ & $56 \%$ & $24 \%$ & $5 \%$ \\
10 & $31 \%$ & $56 \%$ & $13 \%$ & $0 \%$ \\
11 & $2 \%$ & $22 \%$ & $66 \%$ & $10 \%$ \\
12 & $7 \%$ & $48 \%$ & $34 \%$ & $11 \%$ \\
13 & $7 \%$ & $40 \%$ & $48 \%$ & $5 \%$ \\
14 & $10 \%$ & $53 \%$ & $37 \%$ & $0 \%$
\end{tabular}

Sumber: Data diolah

e. Deskripsi data persepsi mahasiswa

Tabel 5. Deskripsi data persepsi mahasiswa

\begin{tabular}{ccccc}
\hline Varians & $\begin{array}{c}\Sigma \\
\text { Mahasiswa }\end{array}$ & $\Sigma$ Skor & $\begin{array}{c}\text { Rata- } \\
\text { rata }\end{array}$ & Kriteria \\
\hline Persepsi Mahasiswa & 247 & 508.82 & 2.06 & Cukup Baik
\end{tabular}




\section{Prosiding Seminar Kesehatan Nasional 2021 Lembaga Penelitian dan Pengabdian Masyarakat Universitas Muhammadiyah Pekajangan Pekalongan}

Berdasarkan data hasil analisis pada table 5 diatas menunjukkan bahwa persepsi mahasiswa Fakultas Ilmu Kesehatan terhadap pembelajaran daring pada masa Pandemi Covid-19 yaitu memiliki rata-rata sebesar 2.06 dengan kategori cukup baik. Hasil penelitian ini menjelaskan bahawa proses pembelajaran daring berlangsung kurang efektif.

\section{Pembahasan}

Dosen dan mahasiswa di Universitas Nahdlatul Wathan Mataram khususnya di Fakultas Ilmu Kesehatan (FIK) diberikan kebebasan untuk menggunakan layanan aplikasi untuk melaksanakan pembelajaran daring. Dosen bisa menggunakan aplikasi google classroom, google meet, zoom, whatsapp group, edmudo maupun layanan elearning Universitas Nahdlatul Wathan Mataram yaitu https://elearn.unwmataram.ac.id/. Istilah pembelajaran daring yaitu pembelajaran yang dilaksanakan secara online dan dibantu oleh aplikasi pembelajaran [10], [11]. Pembelajaran secara online menjadi solusi dan altenatif pemecahan masalah tercepat dalam menghadapi pandemi saat ini. Beberapa penelitian menunjukkan bahwa pembelajaran online pada bidang kesehatan dilakukan melalui teleconference langsung dan simulasi yang dilakukan secara online tanpa bertatap muka langsung [12]. Efektifitas pembelajaran online pada mahasiswa kesehatan khususnya perawat, bidan dan farmasi mencapai $50 \%$, yang artinya proses yang diberikan perlu lebih dioptimalkan kembali melalui inovasi-inovasi yang lebih menarik.

Pembelajaran daring yang dilakukan oleh Fakultas Ilmu Kesehatan pada masa pandemi Covid-19 sangat dimudahkan dengan adanya berbagai pilihan media pembelajaran. Dari berbagai pilihan media yang ada, pola komunikasi yang terbentuk dapat di kelompokkan menjadi tiga macam, yaitu komunikasi satu arah, komunikasi semi dua arah, dan komunikasi dua arah. Berdasarkan hasil penelitian, diperoleh respoden sebanyak $70 \%$ mahasiswa lebih menyukai model komunikasi semi dua arah. seperti whatsapp. Model komunikasi ini diminati oleh banyak mahasiswa karena mahasiswa telah paham dan terbiasa menggunakan chatroom dalam kegiatan sehariharinya, hal ini senada dengan besarnya persentase penggunaan whatsapp sebagai media pembelajaran daring. Selanjutnya, sebanyak 25\% mahasiswa menyukai sistem komunikasi dua arah seperti video conference. Di Fakultas Ilmu Kesehatan, sistem komunikasi dua arah ini pada umumnya memanfaatkan media Zoom, baik yang diunduh pada smartphone, laptop maupun yang diakses melalui Zoom tersebut. Hasil penelitian ini didukung juga oleh hasil penelitian Zhafira, dkk (2020) tentang "Persepsi Mahasiswa Terhadap Perkuliahan Daring Sebagai Sarana Pembelajaran Selama Masa Karantina Covid-19" yaitu pola komunikasi yang paling diminati oleh mahasiswa ialah pola semi dua arah. [13]

Deskripsi dari hasil persepsi mahasiswa pada hasil penelitian terdapat beberapa tanggapan mengenai kemampuan mahasiswa terhadap bebagai media yang digunakan dalam pembelajaran daring menyatakan bahwa mahasiswa masih antusias menyuarakan untuk kegiatan pembelajaran secara tatap muka, penggunaan media sebaiknya fitur yang familiar dan mudah dalam pengaplikasiannya, sebaiknya ada waktu di mana mengkonsep blended learning atau satu pertemuan bertatap muka 


\section{Prosiding Seminar Kesehatan Nasional Lembaga Penelitian dan Pengabdian Masyarakat Universitas Muhammadiyah Pekajangan Pekalongan}

agar penyampaian pembelajaran berjalan efektif dan efisien, bagi dosen lebih kreatif lagi dalam pemanfaatan pembelajaran daring, pemberian tugas pada pembelajaran daring tidak harus setiap pertemuan, keterlambatan pengiriman tugas dan absensi pada pembelajaran daring dikarenakan akses internet di daerah tempat tinggal mahasiswa berbeda-beda, banyak materi yang tidak dipahami jika online, penggunaan platform bervariasi dan sebaiknya hemat kuota misal berupa video materi pembelajaran singkat kirim via whatsapp dan tugas dikirim melalui classroom, sebaiknya materi diberikan sesuai jam matakuliah yang sudah ditetapkan, penggunaan platform yang mudah di akses seperti whatsapp agar respon lebih baik. Hasil penelitian ini didukung juga oleh hasil penelitian Adijaya, dkk (2018) tentang "Persepsi mahasiswa terhadap materi ajar pada pembelajaran online" yaitu respon mahasiswa terhadap lingkungan belajar di perkuliah online belum mendukung mahasiswa belajar. oleh karena itu untuk meningkatkan kulaitas lingkungan belajar dalam perkuliahan online, maka diperlukan dukungan semua pihak. [9]

Hasil penelitian menunjukkan bahwa kendala utama dalam pembelajaran daring berdasarkan tanggapan responden adalah pada parameter penyiapan infrastruktur seperti laptop, smatphone dan internet serta pada respon yang tertunda dari dosen apabila mahasiswa mengajukan pertanyaan yang membuat mahasiswa frustasi. Sikap ini menujukkan bahwa mahasiswa Fakultas Ilmu Kesehatan merasakan kendala lebih besar dibandingkan dengan manfaat yang ada pada pembelajaran daring dengan ratarata persepsi sebesar 2.06 (cukup baik) artinya persepsi mahasiswa lebih banyak memberikan respon negatif pada setiap jawaban tentang efektivitas pembelajaran daring, hal ini sejalan dengan hasil penelitian Muliadi (2021) tentang "Efektivitas Pembelajaran Daring di Masa Pandemi Covid-19: Persepsi Mahasiswa Pendidikan Biologi" yaitu persepsi mahasiswa pendidikan biologi adalah $>70 \%$ memberikan respon negatif pada setiap jawaban tentang efektivitas pembelajaran daring [14]. Berbagai faktor yang perlu diteliti lebih lanjut dapat menjadi pemicu kondisi ini, diantaranya karena kesiapan mahasiswa yang relatif rendah dalam menghadapi perkuliahan daring saat ini. [15]

\section{Kesimpulan}

persepsi mahasiswa FIK UNW Mataram terhadap pembelajaran daring menghasilkan rata-rata sebesar 2.06 atau kategori cukup baik. Oleh sebab itu, dapat disimpulkan bahwa pembelajaran daring di FIK UNW Mataram pada Semester Ganjil 2020/2021 berlangsung kurang efektif.

\section{Ucapan Terima Kasih}

Ucapan terimakaish tidak lupa penulis haturkan ke berbagai pihak: LPPM Universitas NW Mataram selaku pemberi dana penelitian dosen pendanaan tahun 2021, serta ijin penelitian Ketua LPPM Universitas Nahdlatul Wathan Mataram dengan Nomor: 003.1/ST/LPPM.UNW/VI/2021 tanggal 9 Juni 2021. Apt. Hj. Lale Syifaun Nufus, S. Farm, M. Farm selaku Dekan Fakultas Ilmu Kesehatan UNW Mataram. Kepada para reviewer dan proofreader dan pihak pihak lain yang belum dapat penulis sebutkan satu persatu, yang telah membantu dalam penelitian dan penulisan artikel ini. 


\section{Prosiding Seminar Kesehatan Nasional $\mathbf{2 0 2 1}$ Lembaga Penelitian dan Pengabdian Masyarakat Universitas Muhammadiyah Pekajangan Pekalongan}

\section{Referensi}

[1]. Phan LT, Nguyen TV, Luong QC, Nguyen TV, Nguyen HT, Le HQ, Nguyen TT, Cao TM, Pham QD. Importation and human-to-human transmission of a novel coronavirus in Vietnam. New England Journal of Medicine. 27;382(9):872-4, Feb. 2020.

[2]. Nugroho, W.D., Cahyani, W.I., Tobing, A.S., Istiqomah, N., Cahyasari, I., Indrastuti, M., Sugondo, P. and Isworo, A. Literature Review: Transmisi Covid19 dari Manusia ke Manusia di Asia. Journal of Bionursing, 2 (2), pp.101-112. 2020.

[3]. Garg D, Srivastava AK, Dhamija RK. Beyond fever, cough and dyspnea: The neurology of COVID-19. J. Assoc. Physicians India. 1;68(9):62-6, Sep. 2020.

[4]. Hasrul M. Aspek Hukum Pemberlakuan Pembatasan Sosial Berskala Besar (PSBB) Dalam Rangka Penanganan Corona Virus Disease 2019 (Covid-19). Jurnal Legislatif. 22:385-98, Jun. 2020.

[5]. Mutaqinah R, Hidayatullah T. Implementasi Pembelajaran Daring (Program BDR) Selama Pandemi Covid-19 di Provinsi Jawa Barat. Jurnal Petik.;6(2):8695, Sep. 2020.

[6]. DISNAKKESWAN PROV. NTB.. Surat Edaran Gubernur NTB tentang Penyelenggaraan Pembelajaran di Satuan Pendidikan. Retrieved from https://disnakkeswan.ntbprov.go.id/surat-edaran-gubernur-ntb-tentangpenyelenggaraan-pembelajaran-di-satuan-pendidikan/.2020

[7]. Gikas J, Grant MM. Mobile computing devices in higher education: Student perspectives on learning with cellphones, smartphones \& social media. The Internet and Higher Education. 1;19:18-26, Oct. 2013.

[8]. Ningsih, S. Persepsi Mahasiswa Terhadap Pembelajaran Daring Pada Masa Pandemi Covid-19. JINOTEP (Jurnal Inovasi Dan Teknologi Pembelajaran): Kajian Dan Riset Dalam Teknologi Pembelajaran, 7(2), pp.124-132. 2020.

[9]. Adijaya N. Persepsi Mahasiswa dalam Pembelajaran Online** Pengembangan teori dari penelitian berjudul "persepsi mahasiswa terhadap materi ajar pada pembelajaran online" yang telah dipublikasi di Jurnal Eduscience Vol. 3/1. Wanastra: Jurnal Bahasa dan Sastra. 24;10(2):105-10, Sep. 2018

[10]. Rigianti HA. Kendala Pembelajaran Daring Guru Sekolah Dasar Di Banjarnegara. Elementary School: Jurnal Pendidikan dan Pembelajaran ke-SD-an. 1;7(2), Jul. 2020.

[11]. Kamila NA, Susiarno H, Gurnida DA, Afriandi I, Garna H, Djuwantono T. Pengaruh penerapan aplikasi sayang ke buah hati (SEHATI) terhadap pengetahuan ibu dan aktivitas fisik pada anak sekolah dasar. Global Medical and Health Communication. 31;5(2):132-9, Aug. 2017.

[12]. Sofyana L, Rozaq A. Pembelajaran Daring Kombinasi Berbasis Whatsapp Pada Kelas Karyawan Prodi Teknik Informatika Universitas Pgri Madiun. Jurnal Nasional Pendidikan Teknik Informatika: JANAPATI. 10;8(1):81-6, Mar. 2019.

[13]. Zhafira $\mathrm{NH}$, Ertika $\mathrm{Y}$, Chairiyaton C. Persepsi mahasiswa terhadap perkuliahan daring sebagai sarana pembelajaran. Jurnal Bisnis Dan Kajian Strategi Manajemen. Apr 30;4(1). 2020. 


\section{Prosiding Seminar Kesehatan Nasional 2021 Lembaga Penelitian dan Pengabdian Masyarakat Universitas Muhammadiyah Pekajangan Pekalongan}

[14]. Muliadi A, Mirawati B, Jannah H. Efektivitas Pembelajaran Daring di Masa Pandemi Covid-19: Persepsi Mahasiswa Pendidikan Biologi. JISIP (Jurnal Ilmu Sosial dan Pendidikan). 24;5(2), Mar. 2021.

[15]. Kamila, N.A. and Hidayat, A.. Hubungan Motivasi Mengikuti Pendidikan Bidan dengan Minat Belajar pada Mahasiswa DIII Kebidanan Semester II di STIKES'Aisyiyah Yogyakarta. (Doctoral dissertation, STIKES'Aisyiyah Yogyakarta), 2011. 